Original Research Report

\title{
Nurse Caring Attitude Relationships with Parents Patient Satisfaction Level in Public Hospitals Pambalah Batung Amuntai
}

\author{
Rian Tasalim ${ }^{1}$, Mohammad Basit ${ }^{1}$, Rita Agustina $^{2}$ \\ ${ }^{1}$ Medical Surgical Nursing Department, Nursing Program, Faculty of Health, Sari \\ Mulia University. Banjarmasin, Indonesia. \\ ${ }^{2}$ Nursing Practitioner General Hospital Pembalah Batung Amuntai. Banjarmasin, \\ Indonesia.
}

Article History
Received:
28.07 .2021
Revised:
18.08 .2021
Accepted:
02.09 .2021
*Corresponding Author:
M. Sobirin Mohtar
Email:
sobirinmuchtar12345@gmail.com

This is an open access article, licensed under: $C C-B Y-S A$

\begin{abstract}
Caring is a form of nurse's concern for clients. Nurses are required to have the sensitivity and ability to support the trust and wellbeing of patients. Patient/Parent satisfaction is highly dependent on the caring attitude of the nurse. The better the caring attitude of the nurse to the patient, the more the patient will trust the nurse. Nurse caring behavior is one of the determinants of patient satisfaction. The purpose of this study was to determine the relationship between the caring attitude of nurses and the level of satisfaction of the patient's parents in the pediatric ward of Pambalah Batung Amuntai Hospital. Analytic research with a cross sectional approach. Collecting data using a questionnaire. Respondents in the study amounted to 28 people, using probability sampling technique. Data analysis using Chi-Square. The results show that in the pediatric ward of Pambalah Batung Amuntai Hospital, it is known that the caring attitude of nurses in the classification is not good, namely $68 \%$ and the level of satisfaction of parents of patients in the less classification is also as much as $64 \%$ The results of the Chi-Square analysis obtained a significant value of $0.019(\mathrm{p}<0.05)$. There is a relationship between the caring attitude of nurses and the level of satisfaction of parents whose children are cared for in the pediatric care room at Pambalah Batung Amuntai Hospital.
\end{abstract}

Keywords: Caring Family Response, Nurse, Parental Child Satisfaction. 


\section{Introduction}

Nurses are at the forefront of health care. Whether or not the client is satisfied with the health services they get is one of the factors that determine whether or not the quality of service is good or bad. Professional and qualified nurses must have hard skills and soft skills such as caring, empathy and communication [1].

Caring is a form of nurse concern for clients [2]. Nurses must have sensitivity and ability for the well-being and health of clients. The caring attitude of nurses has a great influence on the client care process, especially in hospitals. Because the caring attitude of nurses is one of the determinants of patient satisfaction [3].

The satisfaction of clients who are hospitalized is strongly influenced by the caring attitude of nurses. The better the nurse's caring attitude to the client, the more satisfied and trusting the client will be with the nurse, so that it will accelerate the client's healing process [4].

Child nursing is one of the disciplines in the health sciences that focuses on increasing the growth and development of children, so nurses are fully responsible for providing nursing care to children. In the welfare of children, nursing always prioritizes the interests of children and its efforts cannot be separated from the role of the family so that it always involves the family [5].

Caring attitude in nursing care to clients is very necessary, but in reality there are still many nurses who serve clients without caring. it is known that the caring behavior of implementing nurses in the good category is only $57.9 \%$, and in the less category is $42.1 \%$ [6]. It is known that the caring behavior of nurses in the Inpatient Room of RSAU DR. M. Salamun Bandung is as much as $52.1 \%$ enough [2]. It is known that the caring behavior of nurses at PKU Muhammadiyah Karanganyar Hospital is in the good category (37.5\%), sufficient (41.7\%), less (20.8) with the P velue being 0.000 $<0.05$, which means that the results of this study indicate a close relationship between the caring behavior of nurses and the level of satisfaction [7].

In the Pediatrics Room at Pambalah Batung Amuntai Hospital, during the last 3 months the average number of patients was 30 per month due to the current pandemic situation, initially the average was 150 patients per month, while the level of patient/client satisfaction with services at the RSUD Pambalah Batung Amuntai Pambalah Batung Amuntai based on the results of the 2019 Community Satisfaction Survey towards the Inpatient Installation in this case the patient / patient's family to the quality of service at the Pambalah Batung Amuntai Hospital, especially in the Inpatient Room, to the behavior of the implementer (related to the caring attitude of nurses) was $79.31 \%$ said Satisfied, and 20.69\% Dissatisfied with the behavior of the implementer. Judging from the results of the survey with a figure of $79.31 \%$ saying they are satisfied, it can be said that the community is quite satisfied with the services in the Inpatient Room in general, but seeing the discontent rate reaching $20.69 \%$, this is the impetus for researchers to investigate Furthermore, the level of satisfaction in the Child Care Room, to determine the level of distribution of the dissatisfaction rate, whether the child care room contributed a large number to the survey results or vice versa.

In connection with the target of this study are parents of child patients, due to the limited ability of children in assessing the level of satisfaction felt during treatment in the treatment room, of course those who are also targeted in the results of the survey conducted in 2019 mentioned above are parents patient.

Based on the results of the explanation, the authors are interested in taking the theme, namely "The Relationship of Caring Attitudes with the Satisfaction Level of Parents of Patients in the Child Care Room at Pambalah Batung Amuntai Hospital"

\section{Literature Review}

According to Swanson's theory [8], caring is a holistic nursing that is useful to support the client's healing process and how to establish a caring relationship with the client and take responsibility for the client's condition. Caring is an attitude, respect, care, respect for each other which means giving more attention to others by learning how that person thinks and how someone acts. Caring also contains 3 things that cannot be separated, namely attention, responsibility, and caring with sincerity [6].

In nursing practice Watson has 10 carative factors, namely [8]:

1. Forming an altruksik system, namely giving love and an open attitude to patients.

2. Creating hope and trust, namely establishing relationships with patients to offer help 
3. Increasing sensitivity to oneself and others, namely learning to accept the situation of oneself and others

4. Building help and trust, as well as human caring relationships, namely building communication effectively with patients in realizing trust

5. Promote and express positive and negative feelings, namely supporting and accepting patient feelings in any condition

6. Using creative caring processes in problem solving, namely applying a systematic nursing process and solving patient problems scientifically

7. Promoting transpersonal learning - teaching, namely teaching patients to be skilled in selfcare

8. Providing support, protection, and mental, physical, social, and spiritual improvement, namely restoring the patient's physical and non-physical atmosphere

9. Obtaining human assistance that is to help patients get meet basic needs

10. To allow for the power of phenomena that are spiritual in nature, namely to give a better understanding of the patient's condition

Dimensions of Caring [8] suggests the dimension of caring in nursing services is a service attitude that is assessed by the client, there are four dimensions of caring, among others:

1. With the presence of nurses creating a reassuring atmosphere for clients

2. Recognizing clients as individuals who have unique characteristics with each

3. Maintain a relationship with clients 4 . Give full attention to clients.

There are three factors that influence changes in individual and group behavior, namely:

1. Predisposing factors which are factors that facilitate behavior include knowledge, attitudes, beliefs, social norms and other internal elements, such as lack of spiritual knowledge, fear of making mistakes, nurses' inability to communicate and ambiguity

2. enabling factors, which are factors that enable or facilitate behavior or actions, such as age, social status, education, gender, work experience, marital status and community resources

3. Reinforcing or reinforcing factors that strengthen a person's behavior change include health programs, regulations, laws, policies, and behaviors and attitudes of other health workers such as lack of nurses, lack of time, problems with nurse education and organization management.

Satisfaction is the level of a person's assessment process of something after comparing the results obtained / felt with his previous expectations [10] [11]. Client satisfaction is subjectively associated with the quality of a service obtained by the client and is objectively associated with previous experience, education, environment and psychological state. Factors that affect patient satisfaction [11]. Patient satisfaction is influenced by several aspects, namely:

1. Aspects of comfort, namely the comfort felt by the client during hospitalization, both internal factors such as room comfort and external such as the cleanliness of the surrounding environment, easy and close access and supporting equipment

2. Aspects of the client-nurse relationship (nurse caring attitude), including the nurse's attitude while providing services, the nurse's dexterity in responding to client complaints, effective communication techniques from nurses and clarity of information provided by the patient

3. Aspects of technical competence of nurses, which include the level of education, competence, ability and experience possessed by nurses

4. The cost aspect, including the affordability / low cost incurred by the client during treatment.

The indicator in assessing [11] is the quality of service which has a concept that is often known as SerQual which has 5 (five) dimensions, namely physical evidence, reliability, responsiveness, assurance, and empathy. In order to provide good service quality and satisfy consumers/clients, it is necessary to form good attitudes and behavior from the service provider itself because the human factor holds a very large value in a service which reaches $70 \%$, therefore it is not surprising that the quality of service is not surprising difficult to imitate [12]: 
1. Responsiveness or responsiveness, which is related to the ability of nurses to provide prompt/fast service to clients

2. Releability or reliability, which is related to the accuracy and reliability of the nurse's ability to provide services to clients

3. Assurance, which is related to the ability of nurses in conveying information about health/nursing conditions that occur to clients so as to increase the trust and comfort of clients

4. Empathy or empathy, which is related to the nurse's ability to establish relationships, give attention, and understand the needs of clients. In communicating, nurses involve patients in making the best decisions for themselves

5. Tangible or direct evidence, which is related to facilities and infrastructure that can be felt by patients during treatment, including success in providing care while patients are undergoing treatment and the speed with which nurses respond when patients need them.

\section{Methods}

This type of research is an Analytical Survey, which is a study to find out how and why a phenomenon occurs through a statistical analysis such as the correlation between cause and effect or a risk factor with an effect and then it can be continued to find out how much the contribution of the cause or risk factor to the effect or effects [13]. With a cross-sectional approach, namely research conducted with measurements at one time to correlate Nurse Caring Attitudes to Parental Satisfaction of pediatric patients treated in the Child Care Room at Pambalah Batung Amuntai Hospital the material used is a questionnaire.

\section{Result and Discussion}

Based on the results of this study, it is known that the caring attitude of nurses in the child care room at Pambalah Batung Amuntai Hospital, respondents who stated that nurses were caring were 19 respondents $(68 \%)$ and respondents who stated that their nurses were not caring were 9 respondents (32\%). This shows that the caring attitude of nurses in the child care room at Pambalah Batung Amuntai Hospital is still not good and really needs to be improved.

Table 1. Cross-Tabulation between Nurses' Caring Attitude and Level of Satisfaction

\begin{tabular}{|c|c|c|c|c|c|c|c|}
\hline \multirow{3}{*}{ Caring Attitude } & \multicolumn{4}{|c|}{ Satisfaction Level } & \multirow{2}{*}{\multicolumn{2}{|c|}{ Total }} & \multirow{3}{*}{$P$ velue } \\
\hline & \multicolumn{2}{|c|}{ Not Satisfied } & \multicolumn{2}{|c|}{ Satisfied } & & & \\
\hline & $\mathrm{n}$ & $\%$ & $\mathrm{n}$ & $\%$ & $\mathrm{n}$ & $\%$ & \\
\hline Not Caring & 6 & 66.7 & 3 & 33.3 & 9 & 100 & \multirow{3}{*}{0.019} \\
\hline Caring & 4 & 21.1 & 15 & 78.9 & 19 & 100 & \\
\hline Total & 10 & 35.7 & 18 & 64.3 & 28 & 100 & \\
\hline
\end{tabular}

Based on the results of this study, it is known that the caring attitude of nurses in the child care room at Pambalah Batung Amuntai Hospital, respondents who stated that nurses were caring were 19 respondents (68\%) and respondents who stated that their nurses were not caring were 9 respondents (32\%). This shows that the caring attitude of nurses in the child care room at Pambalah Batung Amuntai Hospital is still not good and really needs to be improved. Caring attitude itself is more influenced by factors from within the nurse herself/character, such as age, length of work, level of education, gender and so on [9]. This is in line with what was expressed which states that there are significant relationship between age and length of work with caring attitudes of nurses [14]. The fact is that in the field it is known that nurses in the child care room are dominated by non-civil servants, namely 7 people (64\%), the level of education is also more diploma 3 , which is 6 people $(54 \%)$, for work experience there are still 3 people (27\%) who work under 5 years, while for gender it is dominated by 8 people $(72 \%)$, so that this characteristic factor is quite influential on the caring attitude of nurses, also states that there is a significant relationship between age, tenure, leadership, organizational structure, rewards and work design with caring attitude of nurses [15]. 
Table 2. Cross-Tabulation between Nurses' Caring Attitudes with Aspects of Satisfaction

\begin{tabular}{|c|c|c|c|c|c|c|c|}
\hline \multirow{3}{*}{ Satisfaction Aspect } & \multicolumn{4}{|c|}{$\begin{array}{c}\text { Category } \\
\text { Caring }\end{array}$} & \multirow{2}{*}{\multicolumn{2}{|c|}{ Total }} & \multirow[t]{3}{*}{$P$ velue } \\
\hline & \multicolumn{2}{|c|}{ Not Caring } & \multicolumn{2}{|c|}{ Caring } & & & \\
\hline & $\mathrm{n}$ & $\%$ & $\mathrm{~N}$ & $\%$ & $\mathrm{~N}$ & $\%$ & \\
\hline \multicolumn{7}{|l|}{ Responsiveness } & \multirow{4}{*}{0.360} \\
\hline Not & 1 & 16.7 & 5 & 33.3 & 6 & 100 & \\
\hline Yes & 8 & 36.3 & 14 & 63.7 & 22 & 100 & \\
\hline Total & 9 & 35.7 & 19 & 64.3 & 28 & 100 & \\
\hline Releability & & & & & & & \multirow{4}{*}{0.002} \\
\hline Not & 6 & 75 & 2 & 25 & 8 & 100 & \\
\hline Yes & 3 & 15 & 17 & 85 & 20 & 100 & \\
\hline Total & 9 & 32 & 19 & 68 & 28 & 100 & \\
\hline \multicolumn{7}{|l|}{ Emphaty } & \multirow{4}{*}{0.022} \\
\hline Not & 6 & 43 & 8 & 57 & 14 & 100 & \\
\hline Yes & 3 & 21.4 & 11 & 78.6 & 14 & 100 & \\
\hline Total & 9 & 35.7 & 19 & 64.3 & 28 & 100 & \\
\hline \multicolumn{7}{|l|}{ Tangible } & \multirow{4}{*}{0.047} \\
\hline Not & 3 & 75 & 1 & 25 & 4 & 100 & \\
\hline Yes & 6 & 25 & 18 & 75 & 24 & 100 & \\
\hline Total & 9 & 35.7 & 19 & 64.3 & 28 & 100 & \\
\hline \multicolumn{7}{|l|}{ Assurance } & \multirow{4}{*}{0.041} \\
\hline Not & 4 & 66.7 & 2 & 33.3 & 6 & 100 & \\
\hline Yes & 5 & 22.7 & 17 & 77.3 & 22 & 100 & \\
\hline Total & 9 & 35.7 & 18 & 64.3 & 28 & 100 & \\
\hline
\end{tabular}

Meanwhile, for the level of satisfaction, the respondents who stated that they were satisfied were as many as 18 respondents $(64 \%)$ and the respondents who stated that their nurses were not caring were as many as 10 respondents $(36 \%)$. This shows that the level of respondents' satisfaction with the services received is still low, which is only $64 \%$. The level of respondent satisfaction is associated with the respondent's character such as gender, education, occupation and sources of respondents' medical expenses, indicating that only gender is considered to affect the assessment of this level of satisfaction, where the value for gender is 0.022 , while for the level of education (0.690), occupation (0.091) and cost sources (0.676) all have a value above 0.05 which indicates that there is no relationship/affects the level of respondent satisfaction, this is in line with research conducted by Stevano et al (2013) which states that there is a relationship between gender and level of satisfaction, in his research it was also stated that the level of education had no relationship/influence on the level of satisfaction, in his research also stated that there was no relationship/influence between job satisfaction and the type of medical expenses [16]. The distribution of respondents' dissatisfaction is spread to the following five factors: Responsiveness is the responsiveness of this matter related to the ability of nurses in providing immediate / fast service to clients, based on this study the respondents' assessment of this responsiveness factor was as many as 6 respondents said they were not satisfied $(21 \%)$ and as many as 22 respondents $(79 \%)$ respondents said they were satisfied with this responsiveness factor, in his research states that this responsiveness factor greatly influences the level of respondent satisfaction, the better the responsiveness, the higher the respondent's satisfaction level, and vice versa the worse the responsiveness, the respondent's satisfaction level will also decrease [17] . Also stated that this factor has an effect/has a relationship on the level of respondent satisfaction [18].

One of the therapeutic communication techniques is the response dimension where nurses must immediately respond spontaneously to patients and families by showing a sincere and appreciative attitude [19]. In the field, it is known that the responsiveness factor has no effect / has no relationship with the level of satisfaction, because based on the Chi-Square test it is known that the relationship 
between responsiveness and satisfaction level produces a $\mathrm{P}$ value of 0.079 , which means that it is greater than 0.05 which indicates that there is no relationship that affects the relationship between responsiveness with respondent satisfaction level. This indicates that the respondent believes that the responsiveness attitude that has been carried out by nurses in the children's room is considered normal or normal by the respondent, so that this responsiveness attitude needs to be improved.

Reliability or reliability is related to the accuracy and reliability of the nurse's ability to provide services to clients. Based on the results of this study, it is known that for this reliability factor, it was found that 8 respondents $(28 \%)$ were not satisfied with this reliability factor and as many as 20 respondents $(72 \%)$ were satisfied with this reliability factor. in his research states that this reliability factor greatly influences the level of respondent satisfaction, the better the reliability, the higher the respondent's satisfaction level, and vice versa the worse the reliability, the respondent's satisfaction level will also decrease [17]. Also stated that this factor has an effect/has a relationship on the level of respondent satisfaction [18].

The fact is that in the field it is known that the reliability factor influences / has a relationship with the level of satisfaction, because based on the Chi-Square test it is known that the relationship between reliability and satisfaction level produces a $\mathrm{P}$ value of 0.000 , which means less than 0.05 which indicates a relationship that affects reliability and level of respondent satisfaction, so that if the reliability is good, the respondent's satisfaction is also good, but if the reliability is less / bad then it will have an impact on the respondent's dissatisfaction while the $r$ value is 0.684 which shows a strong correlation.

Empathy or empathy, which is related to the nurse's ability to establish relationships, give attention, and understand the needs of clients. In communicating, nurses involve patients in making the best decisions for themselves. Based on the results of this study, it is known that for this empathy factor, there are data that as many as 14 respondents $(50 \%)$ are not satisfied with this empathy factor and as many as 14 respondents $(50 \%)$ are satisfied with this empathy factor. in his research stating that this empathy factor greatly influences the level of respondent satisfaction, the better the empathy, the higher the respondent's satisfaction level, and vice versa the worse the empathy, the respondent's satisfaction level will also decrease [17]. Therefore nurses must be able to apply therapeutic communication techniques, one of which is developing empathy. Empathy is an attitude that is able to feel what patients and their families feel so that it has an impact on perceived satisfaction [19]. Also stated that this factor has an effect on/has a relationship to the level of respondent satisfaction [18].

The fact is that in the field it is known that the empathy factor has an influence / relationship with the level of satisfaction, because based on the Chi-Square test it is known that the relationship between empathy and the level of satisfaction produces a $P$ value of 0.017 , which means less than 0.05 which indicates a relationship that affects empathy with the level of satisfaction. respondent satisfaction, so that if the empathy is good then the respondent's satisfaction is also good, but if the empathy is lacking / bad it will have an impact on the respondent's dissatisfaction, while the $r$ value is 0.447 which shows a sufficient correlation.

Tangible or direct evidence, which is related to facilities and infrastructure that can be felt by patients during treatment, including success in providing care while patients are undergoing treatment and the speed with which nurses respond when patients need them. Based on the results of this study, it is known that for this tangible factor, there are data that as many as 4 respondents (14\%) are not satisfied with this tangible factor and as many as 24 respondents $(86 \%)$ are satisfied with this tangible factor. in his research, he stated that this tangible factor greatly influences the level of respondent satisfaction, the better the tangible, the higher the respondent's satisfaction level, and vice versa, the worse the tangible, the respondent's satisfaction level will also decrease [17]. Also stated that this factor has an effect/has a relationship on the level of respondent satisfaction [18].

The fact in the field is it is known that tangible factors do have an effect / have a relationship with the level of satisfaction, because based on the Chi-Square test it is known that the relationship between tangibles and the level of satisfaction produces a $\mathrm{P}$ value of 0.003 , which means less than 0.05 which indicates a relationship that affects between tangible and intangible respondents' satisfaction level, so that if the tangible is good then the respondent's satisfaction is also good, but if the tangible is less / bad it will have an impact on the respondent's dissatisfaction, while the $r$ value is 0.548 which shows a strong correlation.

Assurance or guarantee, which is related to the ability of nurses in conveying information about health/nursing conditions that occur to clients so as to increase client confidence and comfort. Based 
on the results of this study, it is known that for this assurance factor, data obtained that as many as 6 respondents $(21 \%)$ are not satisfied with this assurance factor and as many as 22 respondents $(79 \%)$ are satisfied with this assurance factor. in his research, he stated that this assurance factor greatly influences the level of respondent satisfaction, the better the assurance, the higher the respondent's satisfaction level, and vice versa, the worse the assurance, the respondent's satisfaction level will also decrease [17]. Also stated that this factor has an effect/has a relationship on the level of respondent satisfaction [18].

The fact is that in the field it is known that the assurance factor does have an effect / relationship with the level of satisfaction, because based on the Chi-Square test it is known that the relationship between assurance and the level of satisfaction produces a $\mathrm{P}$ value of 0.000 , which means less than 0.05 which indicates that there is an influencing relationship between assurance and satisfaction respondent's satisfaction level, so that if the assurance is good then the respondent's satisfaction is also good, but if the assurance is poor/poor it will have an impact on the respondent's dissatisfaction, while the $r$ value is 0.701 which indicates a strong correlation.

Based on the results of the analysis of the relationship between the caring attitude of nurses and the level of satisfaction of the respondents, the data obtained that between the caring attitude and the level of satisfaction have a mutually influencing relationship, this is based on the $\mathrm{P}$ value of the relationship between these two variables, which is 0.019 that the caring attitude of nurses with the level of satisfaction has a significant relationship [20]. This is also in line with research [21]. Which states that there is a relationship between nurses' caring attitudes and respondent satisfaction. Likewise, research which states that the caring attitude of nurses and the level of respondent satisfaction is closely related, where if the caring attitude is good then the respondent's satisfaction level will be high, on the contrary if the caring attitude of the nurse is low / bad, the respondent becomes dissatisfied. The $r$ value is 0.445 which shows a fairly strong correlation [22].

According to the Community Satisfaction Index Book made by the Pambalah Batung Amuntai Hospital in 2019, there are 4 assessment intervals for the quality of health services compiled based on Minister of Agriculture Number 14 of 2017, with the category of not good if the value is from 25 64.99 , less good is if the value is from $65-76.60$, the good category is from $76.61-88.30$, and for the very good category the value is between $88.31-100$. RSUD PB (2019).

Based on the results of a community satisfaction survey conducted in 2019 by Pambalah Batung Amuntai Hospital, it is known that the level of community satisfaction with caring behavior, in this case nurses in the inpatient room, obtained a figure of $79.31 \%$ who expressed satisfaction and as many as $20.69 \%$ who stated that they were not satisfied. This means that the results of this study indicate a decrease in the respondent's satisfaction rate, from the previous $79.31 \%$ to $64 \%$ for the level of satisfaction and followed by a decrease in the caring attitude of the nurses which was only $68 \%$. So that this can be an evaluation material in order to improve the quality of hospital services in the future so that a very good community satisfaction index can be achieved. The efforts that can be made by hospitals are to take an individual approach to nurses, namely by increasing the knowledge and skills of caring for their nurses through training, seminars, workshops and through formal nursing education, besides that hospitals can carry out supervision and guidance as well as good role models from superiors in caring behavior.

\section{Summary and Conclusion}

In general, this study aims to determine the relationship between the attitudes of Caring Nurses on the level of satisfaction of parents of child patients who are treated in the Child Care Room at Pambalah Batung Amuntai Hospital. Where the number of samples in this study are 28 people with the following criteria: Parents whose children are cared for in the Child Care Room, Parents whose children are cared for at least $2 \times 24$ hours, and Parents who are willing to become respondents as evidenced by filling out the informed consent. The results of the study indicate that there is a relationship between caring attitude and the level of satisfaction of the patient's parents, this is evidenced by a p-value of 0.019 which means below 0.05 , which indicates a mutually influencing relationship between caring attitudes and respondents' satisfaction levels. 


\section{References}

[1] W. N. Aini, and S. H. Winani, "Perilaku Caring Perawat dalam Memberikan Asuhan Keperawatan di Salah Satu RS di Kabupaten Indramayu-Surabaya," Jurnal keperawatan Profesional (JKP), vol. 7, no. 2, 2019.

[2] F. C. Solehudin and N. Richa, "Perilaku Caring Perawat Berdasarkan Teori Jean Watson di Ruang Rawat Inap, Bandung," Jurnal Kesehatan Vokasional, vol. 4, no. 1, 2019.

[3] K. Erna, "Gambaran Persepsi Pasien Tentang Perilaku Caring Perawat di Ruang Rawat Inap Interna RSUD Kota Makassar,” Jurnal Ilmiah Kesehatan Diagnosis, vol. 13, no. 6, 2019.

[4] Sarjiyem, Hubungan Perilaku Caring Perawat Anestesi dengan Kepuasan Pelayanan Pre Anestesi di Ruang Rawat Inap RSU PKU Muhammadiyah Bantul. Jogja: Poltekes Jogja, 2016.

[5] N. Yuliastati, Keperawatan Anak, Jakarta: Pusdik SDM Kesehatan, 2016.

[6] D. F. Purwaningsih., "Perilaku Caring Perawat Pelaksana di Ruang Rawat Inap Palu," Jurnal Ilmiah Kesehatan, vol. 9, no. 1, pp. 61-67, 2018.

[7] Nabhani, Wijayanti, V. Utami, "Hubungan Caring Perawat dengan Tingkat Kepuasam Pasien, Surakarta," Jurnal Publikasi ITSK PKU Muhammadiyah Surakarya, 2019 [Online]. Available: http://repository.itspku.ac.id/91/1/2016011916.pdf, [Accessed: April. 10, 2021].

[8] J. Watson, "Watson Theoryof Human Caring and Subjective Living Experiences: Carative Factors/Caritas Process as A Disciplinary Guide to Profesional Nursing Practice," Texto Contexto Enferm, vol. 16, no. 1, pp. 129-135, 2017. [Online]. Available: https://www.scielo.br /j/tce/a/yZCPbQkVBhjq6sxxFvwCftC. [Accessed: April. 10, 2021].

[9] D. Mustikaningsih, "Faktor-faktor yang berhubungan dengan perilaku caring perawat dal memberikan spiritual care Islam di Ruang Rawat Inap RS Muhammadiyah Bandung," Bandung, Jurnal Keperawatan Aisyiyah, vol. 5, no. 2, 2018.

[10] R. Daga, Cita, Kualitas Produk dan Kepuasan Pelanggan, Gowa: Global Research and Consulting Institute, 2017.

[11] Kusnanto, Perilaku Caring Perawat Profesional, Surabaya: Pusat Penerbitan dan Percetakan Universitas Airlangga, 2019.

[12] T. A. Ariani and N. Aini "Perilaku Caring Perawat Terhadap Kepuasan Pasien Rawat Inap pada Pelayanan Keperawatan,” E- Jurnal, vol. 9, no. 1, pp. 58-64, 2018.

[13] D. S. Kusuma, R. D. Palupi and S. Andri, Analisis Kepuasan Pelanggan dengan Pendekatan Metode Costomer Satisfaction Index dan Importance Performance Analysis, Malang: Sentra, 2015.

[14] M. Imas and A. Nauri, Metodologi Penelitian Kesehatan, Jakarta: Pusat Pendidikan SDM Kesehatan Kemenkes RI, 2018.

[15] Y. Sukma, "Hubungan Perilaku Caring Perawat dengan tingkat Kepuasan Pasien di Rumah Sakit Permata Bunda Medan Tahun 2019," Jurnal Indonesian Trust Health, vol. 2, no. 1, 2019.

[16] K. Arif, I. Dianing, "Pengaruh Karakteristik Pasien terhadap Indeks Kepuasan Masyarakat tentang Pelayanan Rawat Jalan Puskesmas Banyumas, Porwokerto," Jurnal Kesmasindo, vol. 5, no. 2, pp. 169-179, 2012.

[17] Dasmi, Pengaruh Tangibles, Emphaty, Reliability, Responsiveness dan Assurance Jasa Kesehatan terhadap Kepuasan Pasien Pengguna BPJS pada Puskesmas Sungai Aur Kabupaten Pasaman Barat, Sumatera Barat, Medan: STKIP PGRI Press, 2017.

[18] Mulyaningsih and D. Rizky, "Reliabilitas Mempengaruhi Kepuasan Pasien Terhadap Pelayanan Kesehatan di Salah Satu Puskesmas di Kabupaten Ngawi.” Jurnal Gaster, vol. 10, no.2, 2013.

[19] Sinaulan, "Komunikasi Terapeutik dalam Perspektif Islam," Jurnal Komunikasi Islam, vol. 2, no. 22, 2012.

[20] S. E. Bambang, "Perilaku Caring Perawat dengan Kepuasan Pasien diruang Rawat Inap: Literatur Review," Jurnal Ilmu Keperawatan dan Kebidanan, vol.10, No.1, 2019.

[21] U. P. Eka, and Suryani, "Hubungan Perilaku Caring Perawat dengan Tingkat Kepuasan Pasien di Bangsal Rawat Inap Wardah RS PKU Muhammadiyah Gamping”. Yogjakarta: Universitas Aisyiyah Yogyakarta, 2017.

[22] Niken, "Upaya Peningkatan Caring Perawat terhadap Kepuasan Pasien di Ruang Rawat Inap RS Permata Medika Semarang," Jurnal Manajemen Keperawatan, vol.1, no. 1, 2013. 